ISSN 1678-3921

Journal homepage: www.embrapa.br/pab

For manuscript submission and journal contents, access: www.scielo.br/pab

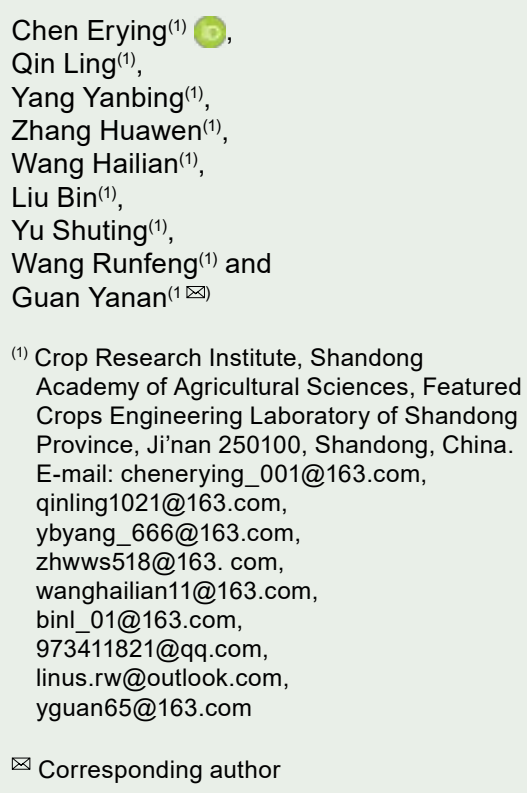

\section{Variability of nitrogen use efficiency by foxtail millet cultivars at the seedling stage}

\begin{abstract}
The objective of this work was to identify the genetic variation of foxtail millet (Setaria italica) cultivars, from three ecogeographic origins in China, regarding the uptake and utilization of $\mathrm{N}$ by the genotypes at the seedling stage, aiming at the genetic improvement of this crop. Seedlings of 79 cultivars were fertilized with a nutrient solution, on a sand substrate, and evaluated under low-N (LN, $0.2 \mathrm{mmol} \mathrm{L}^{-1}$ ) and high-N (HN, $6.0 \mathrm{mmol} \mathrm{L}^{-1}$ ) concentrations. A large variation was observed between cultivars, among the three ecogeographic regions, for shoot biomass, shoot $\mathrm{N}$ content and concentration, and $\mathrm{N}$ use efficiency (NUE), uptake efficiency (NupE), and utilization efficiency (NutE), especially under HN conditions. Cultivars of Northwest China showed the highest variation for shoot biomass, N content, NUE, and NupE. A strong positive correlation was observed between NUE and NupE, and NUE and NutE, but there was no correlation between NupE and NutE. NupE accounted for $77.6 \%$ of the total variation of NUE, and NutE for the rest. The uptake and utilization of $\mathrm{N}$ show a large variation among the foxtail millet cultivars at the seedling stage, and the variation of $\mathrm{N}$ uptake contributes more than that of $\mathrm{N}$ utilization to the variation of $\mathrm{N}$ use efficiency.
\end{abstract}

Index terms: Setaria italica, ecological cultivars, nitrogen uptake efficiency.

\section{Variabilidade da eficiência de uso de nitrogênio por cultivares de milheto no estádio de plântulas}

Resumo - O objetivo deste trabalho foi identificar a variação genética de cultivares de milheto (Setaria italica), de três origens ecogeográficas da China, quanto à captação e à utilização de $\mathrm{N}$ pelos genótipos no estádio de plântulas, com vistas ao melhoramento genético desta cultura. Plântulas de 79 cultivares de milheto foram fertilizadas com uma solução nutritiva, em substrato de areia, e avaliadas em condições de baixa ( $\left.\mathrm{LN}, 0,2 \mathrm{mmol} \mathrm{L}^{-1} \mathrm{~N}\right)$ e alta $\left(\mathrm{HN}, 6,0 \mathrm{mmol} \mathrm{L}^{-1} \mathrm{~N}\right)$ concentração de $\mathrm{N}$. Observou-se uma grande variação entre as cultivares, entre as origens ecogeográficas, quanto às características biomassa da parte aérea, teor e concentração de $\mathrm{N}$ na parte aérea, e eficiência de uso (NUE), captação (NupE) e utilização (NutE) de $\mathrm{N}$, especialmente em condições de HN. As cultivares do Noroeste da China apresentaram as maiores variações de biomassa, teor de N, NUE e NupE. Observou-se, ainda, uma forte correlação positiva entre NUE e NupE, e NUE e NutE, mas não houve correlação entre NupE e NutE. O NupE representou $77,6 \%$ da variação total do NUE, e o NutE representou o restante. A captação e a utilização de $\mathrm{N}$ apresentam grande variação entre cultivares de milheto no estágio de plântulas, e a variação da captação de $\mathrm{N}$ contribui mais do que a da utilização de $\mathrm{N}$ para a variação da eficiência de uso de nitrogênio.

Termos para indexação: Setaria italica, cultivares ecológicas, eficiência de absorção de nitrogênio. 


\section{Introduction}

Foxtail millet, Setaria italica (L.) Beauv. - a self pollinating $\mathrm{C}_{4}$ plant and one of the ten small-grained cereals (small millets) - is an important grain crop used as staple food in some regions of China, India, and Japan, and is grown for animal feed in the USA and Europe (Austin et al., 2006; Upadhyaya et al., 2011). Foxtail millet shows a small diploid genome, and has become a model plant for biofuel crops and genomic study for $\mathrm{C}_{4}$ carboxylase pathway and short growing duration (Jia et al., 2013). It has been reported as tolerant to drought, salinity, and infertile soil, and thought to be environmentally friendly crop (Doust et al., 2009).

In the past years, the planting area of foxtail millet has declined seriously because of its low-grain yield (in comparison with other staple cereals) that can not meet the food demand by people (Vetriventhan et al., 2012). However, in recent years, grain yields of foxtail millet have raised substantially under breeders' effort (Diao, 2007). Nevertheless, cereal crops are inefficient in the use of $\mathrm{N}$ fertilizer, as about $33 \%$ only of the $\mathrm{N}$ fertilizer applied to the crop is recovered in aboveground plant biomass, at the end of the cropping season (Garnett et al., 2009).

In China, a large amount of external $\mathrm{N}$ input was used in order to achieve a higher-grain yield, which had caused a severe environment pollution and a low-N fertilizer use efficiency (NUE) (Peng et al., 2010; Chen et al., 2014a; Liu et al., 2019). Therefore, considerable researches and extension works were undertaken to improve the $\mathrm{N}$ use efficiency (Chen et al., 2014b; Hou et al., 2019). The use of foxtail millet cultivars with higher-NUE is an important approach for sustainable agriculture (Storer et al., 2018; Haegele et al., 2013; Chen et al., 2014b). Although a lot of research on the genetic differences in NUE have been reported for most cereal crops - including wheat, rice, maize, sorghum, and barley (Kant et al., 2011; Ju et al., 2015) -, they are not yet known for such differences in foxtail millet.

Seedling stage, as an important period of crop growth, determines the developing of crop production and final grain yield. Crops have been reported as poor users of both available $\mathrm{N}$ and applied $\mathrm{N}$ fertilizer at the seedling stage because of the poor synchronization between the availability of $\mathrm{N}$ and the demand for $\mathrm{N}$ (Liao et al., 2004), which results in the potential for significant $\mathrm{N}$ losses. Hence, it is very important to know how to settle the inconsistence between $\mathrm{N}$ availability and crop demand, and increase the $\mathrm{N}$ use efficiency, which could be achieved from using germplasm with higher-N uptake and utilization efficiency at early growing season (Pang et al., 2014).

However, the evaluation of highly nitrogen efficient cultivars, for physiological mechanism study and breeding in foxtail millet, is yet to be undertaken.

The objective of this work was to identify the genetic variation of foxtail millet (Setaria italica) cultivars from three ecogeographic origins of China, regarding the uptake and utilization of $\mathrm{N}$ in genotypes at the seedling stage, aiming at the genetic improvement of this crop.

\section{Materials and Methods}

The experiments were carried out in a greenhouse, in the Shandong Academy of Agricultural Sciences, in Ji'nan city, in the province of Shandong, China, from May 2016 to June 2016.

The experiment was carried out in a completely randomized design, with four replicates, and two $\mathrm{N}$ condition treatments: $0.2 \mathrm{mmol} \mathrm{L}^{-1}$ (low-N) and $6 \mathrm{mmol}$ $\mathrm{L}^{-1}$ (high-N). Seventy-nine foxtail millet cultivars, from three ecogeographic origins, were evaluated as follows: 37 from North China (NC), a summer sowing region; 25 from Northwest China (NWCC), a spring sowing region; and 17 from Northeast China (NEC), a spring sowing region (Table 1). Seed of the cultivars were sown on 20 May 2016, in rectangular plastic pots with the following dimensions: 0.5 width, $0.4 \mathrm{~m}$ height and $0.8 \mathrm{~m}$ length, with permeable bottom; the pots were filled with $35 \mathrm{~kg}$ sand substrate of $1.28 \mathrm{~g} \mathrm{~cm}^{-3}$ bulk density. The substrate was washed with purified water to avoid the sticking of nutrients. Seed were sown in twelve rows in the pot at $15 \mathrm{~kg} \mathrm{ha}^{-1}$ seeding rate. One week after sowing, the seedlings were thinned to the density of 60 plant per pot. The pots were watered once every two days with purified water according to their weight, in order to maintain the sand water content close to $70 \%$ of field capacity before seedling emergence. Plants were watered once with modified Hoagland nutrient solution (with different $\mathrm{N}$ content for two $\mathrm{N}$ treatments), every two days after emergence. Before the spraying of the nutrient solution, the pots 
were always watered enough with purified water to wash off the residual nutrient element.

The plants were grown in the greenhouse under 26$16^{\circ} \mathrm{C}$ as a mean day-night temperature and $70 \% \mathrm{RH}$, and 4 weeks after sowing, they were harvested. Shoots were separated from roots at the ground level, dried at

Table 1. Foxtail millet (Setaria italica) cultivars from three ecogeographic origins in China.

\begin{tabular}{|c|c|c|c|c|c|c|c|}
\hline $\mathrm{N}^{\circ}$ & Cultivar & Type & $\begin{array}{c}\text { Loca- } \\
\text { lity }\end{array}$ & $\mathrm{N}^{\circ}$ & Cultivar & Type & $\begin{array}{c}\text { Loca- } \\
\text { lity }\end{array}$ \\
\hline 1 & Lujin1 & $\mathrm{NC}$ & SD & 41 & Jingu29 & NWC & SX \\
\hline 2 & Lujin3 & $\mathrm{NC}$ & SD & 42 & Qingzhenzhu & NWC & SX \\
\hline 3 & Lujin5 & $\mathrm{NC}$ & SD & 43 & Jinfen03 & NWC & SX \\
\hline 4 & Liaonong1 & $\mathrm{NC}$ & SD & 44 & Jingu34 & NWC & SX \\
\hline 5 & Lugu1 & $\mathrm{NC}$ & SD & 45 & Jingu41 & NWC & SX \\
\hline 6 & Lugu2 & $\mathrm{NC}$ & SD & 46 & Jingu45 & NWC & SX \\
\hline 7 & Lugu3 & $\mathrm{NC}$ & SD & 47 & Jingu46 & NWC & SX \\
\hline 8 & Lugu4 & $\mathrm{NC}$ & SD & 48 & Jingu48 & NWC & SX \\
\hline 9 & Lugu5 & $\mathrm{NC}$ & SD & 49 & Datong32 & NWC & SX \\
\hline 10 & Lugu6 & $\mathrm{NC}$ & SD & 50 & Jingu39 & NWC & SX \\
\hline 11 & Lugu7 & $\mathrm{NC}$ & SD & 51 & Longgu5 & NWC & SAX \\
\hline 12 & Lugu8 & $\mathrm{NC}$ & SD & 52 & Longgu7 & NWC & SAX \\
\hline 13 & Lugu9 & $\mathrm{NC}$ & SD & 53 & Longgu10 & NWC & SAX \\
\hline 14 & Lugu10 & $\mathrm{NC}$ & SD & 54 & Longgu11 & NWC & SAX \\
\hline 15 & Ji8062-8 & $\mathrm{NC}$ & SD & 55 & $\begin{array}{l}\text { Shenshehuan- } \\
\text { gmaogu }\end{array}$ & NWC & SX \\
\hline 16 & Jigu12 & $\mathrm{NC}$ & SD & 56 & Jinguoyin & NWC & SX \\
\hline 17 & Jigu13 & $\mathrm{NC}$ & SD & 57 & Neihuaguzi180 & NWC & SX \\
\hline 18 & Jigu14 & $\mathrm{NC}$ & SD & 58 & Neixiaoxiangyu & NWC & SX \\
\hline 19 & Jigu15 & $\mathrm{NC}$ & SD & 59 & Yangu2 & NWC & SAX \\
\hline 20 & Gufeng1 & $\mathrm{NC}$ & HB & 60 & Yangu 12 & NWC & SAX \\
\hline 21 & Jigu20 & $\mathrm{NC}$ & HB & 61 & Qingu3 & NWC & SAX \\
\hline 22 & Jigu24 & $\mathrm{NC}$ & HB & 62 & Yannongjiazhong & NWC & SAX \\
\hline 23 & Jigu26 & $\mathrm{NC}$ & HB & 63 & Chigu7 & NEC & IM \\
\hline 24 & Jigu29 & $\mathrm{NC}$ & $\mathrm{HB}$ & 64 & Chigu8 & NEC & IM \\
\hline 25 & Xiaoxiangmi & $\mathrm{NC}$ & HB & 65 & Longgu25 & NEC & HLJ \\
\hline 26 & Jixiang1 & $\mathrm{NC}$ & HB & 66 & Longgu31 & NEC & HLJ \\
\hline 27 & Qingfenggu & $\mathrm{NC}$ & $\mathrm{HB}$ & 67 & Longgu32 & NEC & HLJ \\
\hline 28 & Baogu18 & $\mathrm{NC}$ & HB & 68 & Longgu34 & NEC & HLJ \\
\hline 29 & Yugu3 & $\mathrm{NC}$ & $\mathrm{HN}$ & 69 & Chaogu12 & NEC & LN \\
\hline 30 & Yugu4 & $\mathrm{NC}$ & $\mathrm{HN}$ & 70 & Chaogu14 & NEC & LN \\
\hline 31 & Yugu8 & $\mathrm{NC}$ & $\mathrm{HN}$ & 71 & Yangu16 & NEC & LN \\
\hline 32 & Yugu9 & $\mathrm{NC}$ & $\mathrm{HN}$ & 72 & Gongai2 & NEC & $\mathrm{JL}$ \\
\hline 33 & Yugu13 & $\mathrm{NC}$ & $\mathrm{HN}$ & 73 & Gongai5 & NEC & $\mathrm{JL}$ \\
\hline 34 & Yugu14 & $\mathrm{NC}$ & $\mathrm{HN}$ & 74 & Gongai6 & NEC & $\mathrm{JL}$ \\
\hline 35 & Yugu15 & $\mathrm{NC}$ & $\mathrm{HN}$ & 75 & Gongai8 & NEC & $\mathrm{JL}$ \\
\hline 36 & Yugu17 & $\mathrm{NC}$ & $\mathrm{HN}$ & 76 & Gonggu60 & NEC & $\mathrm{JL}$ \\
\hline 37 & $93-15$ & $\mathrm{NC}$ & $\mathrm{HN}$ & 77 & Gonggu65 & NEC & $\mathrm{JL}$ \\
\hline 38 & Jingu30 & NWC & SX & 78 & Gonggu72 & NEC & $\mathrm{JL}$ \\
\hline 39 & Changgu4 & NWC & SX & 79 & Gonggu75 & NEC & $\mathrm{JL}$ \\
\hline 40 & Changsheng4 & NWC & SX & & & & \\
\hline
\end{tabular}

NC, North China, summer; NWC, Northwest China; NEC, Northeast China; SD, Shandong province; HB, Hebei province; HN, Henan province; SX, Shanxi province; SAX, Shaanxi province; ${ }^{(9)}$ IM, Inner Mongolia Autonomous Region; HLJ, Heilongjiang province; LN, Liaoning province; JL, Jilin province. $70^{\circ} \mathrm{C}$ for 48 hours and weighed. The oven-dried shoots were then ground into powder for measurement. The $\mathrm{N}$ concentration in the shoots was measured using the Kjeldahl method.

NUE was calculated as the ratio of shoot dry matter to the amount of supplied N, and multiplied a hundred percent. NupE was calculated by dividing the shoot-N content by the supplied $\mathrm{N}$ amount, and multiplied a hundred percent. The $\mathrm{N}$ utilization efficiency (NutE) was calculated as the ratio of shoot dry matter to the shoot-N content, and multiplied a hundred percent. The analyses of variance using the F-test, at $95 \%$ probability, with the Statistical Product and Service Solutions software (SPSS) were used to test the differences for shoot biomass, $\mathrm{N}$ content, $\mathrm{N}$ concentration, NUE, NupE, and NutE between cultivars and $\mathrm{N}$ treatments, and the coefficient of variation $(\mathrm{CV} \%)$ was calculated. The contribution of variation in NupE and NutE to the variation in NUE was determined according to Bingham et al. (2012). All determinations were replicated three times in each sample.

\section{Results and Discussion}

There were significant differences among $\mathrm{N}$ treatments, cultivars, and the interaction between them (Table 2). Shoot biomass, shoot-N content, and shoot-N concentration at the seedling stage ranged significantly among cultivars (Table 3 ). The cultivars also varied significantly for NupE, NutE, and NUE, which showed that there had a significant variation of shoot biomass and nitrogen use among the different foxtail millet cultivars.

Shoot biomass, $\mathrm{N}$ content, and $\mathrm{N}$ concentration increased from $0.12 \mathrm{~g}$ per plant, $1.39 \mathrm{mg}$ per plant, and $1.17 \%$, under $\mathrm{LN}$ condition, to $0.22 \mathrm{~g}$ per plant, $5.21 \mathrm{mg}$ per plant, and $2.43 \%$, respectively, under HN condition (Table 3). NUE, NupE and NutE, in response to $\mathrm{N}$ level application, decreased from 42.82 $\mathrm{g} \mathrm{g}^{-1}, 49.70 \%$, and $86.07 \mathrm{~g} \mathrm{~g}^{-1}$ under LN condition to $2.58 \mathrm{~g} \mathrm{~g}^{-1}, 6.21 \%$, and $41.42 \mathrm{~g} \mathrm{~g}^{-1}$, respectively, under HN condition. Similar results have been reported for pearl millet (Singh et al., 2010). Shoot biomass showed the highest coefficient of variation (CV), followed by shoot-N content, NUE, NupE, and NutE. Nitrogen concentration in the shoots showed the lowest CV, under both $\mathrm{LN}$ and $\mathrm{HN}$ conditions. The variation of NupE explained $77.6 \%$, and NutE, $22.4 \%$, of the 
variation in NUE. The contribution of NupE to NUE increased from $74.1 \%$ under LN to $81.1 \%$ under HN. The CVs of shoot biomass, shoot-N content, NUE, and NupE under HN supply also increased from LN to HN, whereas the CVs of shoot-N concentration and NutE were similar both under LN and HN. These results are indicative that $\mathrm{HN}$ supply was advantageous to increase the phenotypic variation of early growth and $\mathrm{N}$ uptake in foxtail millet, but had no effect on the variation of plant shoot- $\mathrm{N}$ concentration and $\mathrm{N}$ use among cultivars at the seedling stage.

The early growth (shoot biomass, $\mathrm{N}$ content, $\mathrm{N}$ concentration) and NUE were different among the three ecogeographic types (Table 4). There was interaction between ecogeographic types and N treatments. Shoot biomasses of the three ecogeographic types were similar under LN, while shoot biomasses of the NC summer type and NEC type were higher than those of the NWCC type under HN. In both N conditions, the ecogeographic types had the following results: the NWCC type showed the highest CV of shoot biomass, and the NEC type, the lowest one; the NEC type showed the highest-N content, and the NWCC type, the highest CV of shoot-N content. There were no differences in shoot-N concentration and $\mathrm{CV}$ among the three ecogeographic types under LN. The $\mathrm{N}$ type had the highest- $\mathrm{N}$ concentration and $\mathrm{CV}$ of $\mathrm{N}$ concentration under $\mathrm{HN}$.

The NUE was lower in HN condition, in the three ecogeographic types, which ranged from 15.3 times (NEC), 15.6 times (NC) to 19.8 times (NWCC) (Table 5). Under LN, the NEC type had the highest NUE, NupE, and NutE, followed by the NWCC type; and the NC type had the lowest NUE and its components. The NWCC type had the highest CV of NUE and NupE, and the NC type had the highest $\mathrm{CV}$ of NutE. While under HN, the NEC type had the highest NUE, NupE, and NutE. The NWCC type had the highest CV of NUE and NupE; and the NC type had the highest-CV of NutE under HN. The contribution of NupE to NUE under the NWCC, NC, and NEC types was $81.8,75.2$, and $76.5 \%$, respectively.

The NEC type had the highest shoot biomass under $\mathrm{HN}$, as well as the highest $\mathrm{N}$-content, the highest NUE, and the highest NupE under both LN and HN. The CV of these traits was the highest in the NWC type, which means that the cultivars of the NEC type were more vigorous, and the cultivar variation of the NWC type was wider for the early growth and nitrogen use.

Table 2. Analysis of variance of the $\mathrm{F}$ values for shoot biomass, shoot-N content, shoot-N concentration, nitrogen use efficiency, nitrogen uptake efficiency and nitrogen utilization efficiency of foxtail millet (Setaria italica) cultivars.

\begin{tabular}{lccccccc}
\hline Source of variation & DF & Shoot biomass & Shoot-N content & Shoot-N concentration & NUE & NupE & NutE \\
\hline N treatment (N) & 1 & $152.34^{* *}$ & $423.94^{* *}$ & $4290.00^{* *}$ & $1205.82^{* *}$ & $1320.40^{* *}$ & $4092.20^{* *}$ \\
Cultivar (C) & 78 & $1.90^{* *}$ & $1.42^{* *}$ & $2.17^{* *}$ & $1.18^{* *}$ & $1.43^{* *}$ & $2.12^{* *}$ \\
$\mathrm{C} \times \mathrm{N}$ & 78 & $34.60^{* *}$ & $132.46^{* *}$ & $6.39^{* *}$ & $14.84^{* *}$ & $24.75^{* *}$ & $3.33^{* *}$ \\
\hline
\end{tabular}

$* *$ Significant at $1 \%$ probability.

Table 3. Mean, range, and coefficient variation(CV) of shoot biomass, shoot-N content, shoot-N concentration, nitrogen use efficiency(NUE), nitrogen uptake efficiency(NupE), and nitrogen utilization efficiency (NutE) for 79 foxtail millet (Setaria italica) cultivars under low- (LN) and high- (HN) nitrogen conditions.

\begin{tabular}{|c|c|c|c|c|c|c|}
\hline \multirow[t]{2}{*}{ Characteristic } & \multicolumn{2}{|c|}{ Mean } & \multicolumn{2}{|c|}{ Range } & \multicolumn{2}{|c|}{$\mathrm{CV}(\%)$} \\
\hline & $\mathrm{LN}$ & $\mathrm{HN}$ & $\mathrm{LN}$ & $\mathrm{HN}$ & $\mathrm{LN}$ & $\mathrm{HN}$ \\
\hline Shoot biomass (g plant) & 0.12 & 0.22 & $0.05-0.20$ & $0.09-0.40$ & 35.39 & 50.83 \\
\hline Shoot-N content (mg/plant) & 1.39 & 5.21 & $0.64-2.22$ & $1.95-9.82$ & 32.82 & 48.46 \\
\hline Shoot-N concentration $(\%)$ & 1.17 & 2.43 & $0.98-1.39$ & $2.05-2.89$ & 11.52 & 11.22 \\
\hline $\operatorname{NUE}\left(\mathrm{g} \mathrm{g}^{-1}\right)$ & 42.82 & 2.58 & $17.74-70.54$ & $1.01-4.73$ & 35.35 & 50.61 \\
\hline NupE $(\%)$ & 49.70 & 6.21 & $22.91-79.54$ & $2.32-11.70$ & 32.82 & 48.45 \\
\hline $\operatorname{NutE}\left(\mathrm{g} \mathrm{g}^{-1}\right)$ & 86.07 & 41.42 & $72.27-102.20$ & $34.60-49.67$ & 11.53 & 11.27 \\
\hline
\end{tabular}


According to the means of shoot biomass, NUE, N content, NupE, N concentration, and NutE of under LN and $\mathrm{HN}$, the 79 cultivars of the three ecogeographic types were divided into four types: higher than the means under LN and HN (HLHH); lower than the means under LN and HN (LLLH); higher than the means under LN and lower than the means under HN (HLLH); and lower than the means under LN and higher than the means under HN (LLHH) (Figure 1). The different cultivars described in the present study could provide useful materials for their inclusion in breeding programs aiming at the genetic improvement for $\mathrm{N}$ uptake and $\mathrm{N}$ utilization, and for exploiting the understanding mechanisms driving the genotypic variation for $\mathrm{N}$ uptake and $\mathrm{N}$ utilization.

Across all cultivars, NUE was positively correlated with its components NupE and NutE, and the difference of NupE contributed more to the variation in NUE than NutE (Figure 2). The results were in agreement with other studies showing that the variation in NUE among cultivars was associated with difference in NupE and NutE; they also showed that most of the variation in NUE among cultivars was associated with differences in NupE rather than NutE (Muurinen et al., 2006; Sylvester-Bradley \& Kindred, 2009; Bingham et al., 2012). On this basis, shoot biomass was positively

Table 4. Mean, coefficient of variation (CV), and range of shoot biomass, shoot-N content, shoot-N concentration of cultivars from three eco-geographic types of foxtail millet (Setaria italica), under low- (LN) and high- (HN) nitrogen supply.

\begin{tabular}{|c|c|c|c|c|c|c|c|c|c|c|}
\hline \multirow[t]{2}{*}{$\mathrm{N}$ rate } & \multirow{2}{*}{$\begin{array}{l}\text { Ecogeographic } \\
\text { regions }\end{array}$} & \multicolumn{3}{|c|}{ Biomass (g per plant) } & \multicolumn{3}{|c|}{$\mathrm{N}$ content (mg per plant) } & \multicolumn{3}{|c|}{$\mathrm{N}$ concentration $(\%)$} \\
\hline & & Mean & CV (\%) & Range & Mean & CV (\%) & Range & Mean & CV (\%) & Range \\
\hline \multirow{3}{*}{$\mathrm{LN}$} & $\mathrm{NC}$ & $0.12 \mathrm{a}$ & $31.82 \mathrm{~b}$ & $0.08-0.18$ & $1.37 \mathrm{~b}$ & $29.31 b$ & $0.99-1.94$ & $1.17 \mathrm{a}$ & $11.68 \mathrm{a}$ & $0.98-1.37$ \\
\hline & NWC & $0.12 \mathrm{a}$ & $42.98 \mathrm{a}$ & $0.05-0.20$ & $1.39 \mathrm{~b}$ & $39.99 \mathrm{a}$ & $0.64-2.18$ & $1.17 \mathrm{a}$ & $11.69 \mathrm{a}$ & $1.03-1.32$ \\
\hline & NEC & $0.12 \mathrm{a}$ & $29.22 \mathrm{c}$ & $0.07-0.17$ & $1.44 \mathrm{a}$ & $29.48 b$ & $0.92-2.22$ & $1.17 \mathrm{a}$ & $11.61 \mathrm{a}$ & $1.05-1.39$ \\
\hline \multirow{3}{*}{$\mathrm{HN}$} & $\mathrm{NC}$ & $0.23 \mathrm{a}$ & $48.22 b$ & $0.10-0.40$ & $5.52 b$ & $45.67 b$ & $2.71-9.82$ & $2.45 \mathrm{a}$ & $12.20 \mathrm{a}$ & $2.01-2.83$ \\
\hline & NWC & $0.18 b$ & $56.48 \mathrm{a}$ & $0.09-0.31$ & $4.43 \mathrm{c}$ & $54.40 \mathrm{a}$ & $1.95-7.60$ & $2.44 \mathrm{a}$ & $9.47 \mathrm{c}$ & $2.13-2.71$ \\
\hline & NEC & $0.24 \mathrm{a}$ & $42.98 \mathrm{c}$ & $0.10-0.36$ & $5.69 \mathrm{a}$ & $40.31 \mathrm{c}$ & $2.38-8.15$ & $2.37 \mathrm{~b}$ & $11.22 b$ & $2.13-2.89$ \\
\hline $\mathrm{F}_{\mathrm{N}}$ & & $2,102.7 * *$ & $1,453.1 * *$ & & $105,426.3^{* *}$ & $8,007.1 * *$ & & $35,002.2 * *$ & $273.43 * *$ & \\
\hline $\mathrm{F}_{\mathrm{C}}$ & & $60.63 * *$ & $450.33 * *$ & & $1,159.2 * *$ & $2,334.8^{* *}$ & & $12.26^{*}$ & $352.06^{* *}$ & \\
\hline $\mathrm{F}_{\mathrm{C}^{\prime} \mathrm{N}}$ & & $60.63 * *$ & $5.90^{*}$ & & $1,092.0 * *$ & $109.68 * *$ & & $18.27 * *$ & $361.13 * *$ & \\
\hline
\end{tabular}

*, **Significant at 5 and 1\% probability, respectively. NC, North summer; NWC, Northwest; NE, Northeast.

Table 5. Mean, coefficient of variation (CV), and range of nitrogen use efficiency(NUE), nitrogen uptake efficiency (NupE), and nitrogen utilization efficiency (NutE) of foxtail millet (Setaria italica) cultivars (of three ecogeographic regions in China), under low- (LN) and high- (HN) nitrogen conditions.

\begin{tabular}{|c|c|c|c|c|c|c|c|c|c|c|}
\hline \multirow{2}{*}{$\begin{array}{l}\mathrm{N} \\
\text { rate }\end{array}$} & \multirow{2}{*}{$\begin{array}{l}\text { Ecogeographic } \\
\text { regions }\end{array}$} & \multicolumn{3}{|c|}{$\operatorname{NUE}\left(\mathrm{g} \mathrm{g}^{-1}\right)$} & \multicolumn{3}{|c|}{$\operatorname{NupE}(\%)$} & \multicolumn{3}{|c|}{ NutE $\left(\mathrm{g} \mathrm{g}^{-1}\right)$} \\
\hline & & Mean & CV (\%) & Range & Mean & CV (\%) & Range & Mean & $\mathrm{CV}(\%)$ & Range \\
\hline \multirow{3}{*}{$\mathrm{LN}$} & $\mathrm{NC}$ & $42.00 \mathrm{~b}$ & $32.15 b$ & $27.68-65.77$ & $48.78 b$ & $29.31 \mathrm{~b}$ & $35.24-69.36$ & $86.09 \mathrm{a}$ & $12.03 \mathrm{a}$ & $72.85-102.20$ \\
\hline & NWC & $43.18 \mathrm{ab}$ & $43.10 \mathrm{a}$ & $17.74-70.54$ & $49.82 b$ & $39.99 a$ & $22.91-77.84$ & $86.35 \mathrm{a}$ & $11.50 \mathrm{~b}$ & $75.65-97.42$ \\
\hline & $\mathrm{NE}$ & $44.07 \mathrm{a}$ & $30.49 \mathrm{c}$ & $25.60-60.12$ & $51.52 \mathrm{a}$ & $29.49 \mathrm{~b}$ & $33.01-79.45$ & $85.63 \mathrm{a}$ & $11.09 \mathrm{c}$ & $72.27-95.69$ \\
\hline \multirow{3}{*}{$\mathrm{HN}$} & $\mathrm{NC}$ & $2.70 \mathrm{~b}$ & $48.01 \mathrm{~b}$ & $1.23-4.73$ & $6.57 b$ & $45.68 \mathrm{~b}$ & $3.23-11.70$ & $41.09 \mathrm{~b}$ & $12.70 \mathrm{a}$ & $35.33-49.67$ \\
\hline & NWC & $2.18 \mathrm{c}$ & $56.29 \mathrm{a}$ & $1.01-3.71$ & $5.28 \mathrm{c}$ & $54.38 \mathrm{a}$ & $2.32-9.05$ & $41.22 \mathrm{~b}$ & $9.51 \mathrm{c}$ & $36.85-46.99$ \\
\hline & $\mathrm{NE}$ & $2.88 \mathrm{a}$ & $42.20 \mathrm{c}$ & $1.14-4.31$ & $6.77 \mathrm{a}$ & $40.30 \mathrm{c}$ & $2.83-9.70$ & $42.43 \mathrm{a}$ & $10.29 b$ & $34.60-46.88$ \\
\hline $\mathrm{F}_{\mathrm{N}}$ & & $55,733.8 * *$ & $1,284.4 * *$ & & $63,434.0^{* *}$ & $8,101.7^{* *}$ & & $15,797.3^{* *}$ & 197.90 ** & \\
\hline $\mathrm{F}_{\mathrm{CT}}$ & & $15.15^{* *}$ & $440.47 * *$ & & $34.80 * *$ & $2,362.2 * *$ & & $0.51^{\mathrm{ns}}$ & $551.13^{* *}$ & \\
\hline $\mathrm{F}_{\mathrm{CT}^{\prime} \mathrm{N}}$ & & $12.27 *$ & $10.26^{*}$ & & $21.96 * *$ & $111.29 * *$ & & $3.11^{\mathrm{ns}}$ & $234.23 * *$ & \\
\hline
\end{tabular}

*, **Significant at 5 and $1 \%$ probability, respectively. NC, North China, summer; NWC, Northwest; NEC, Northeast. 

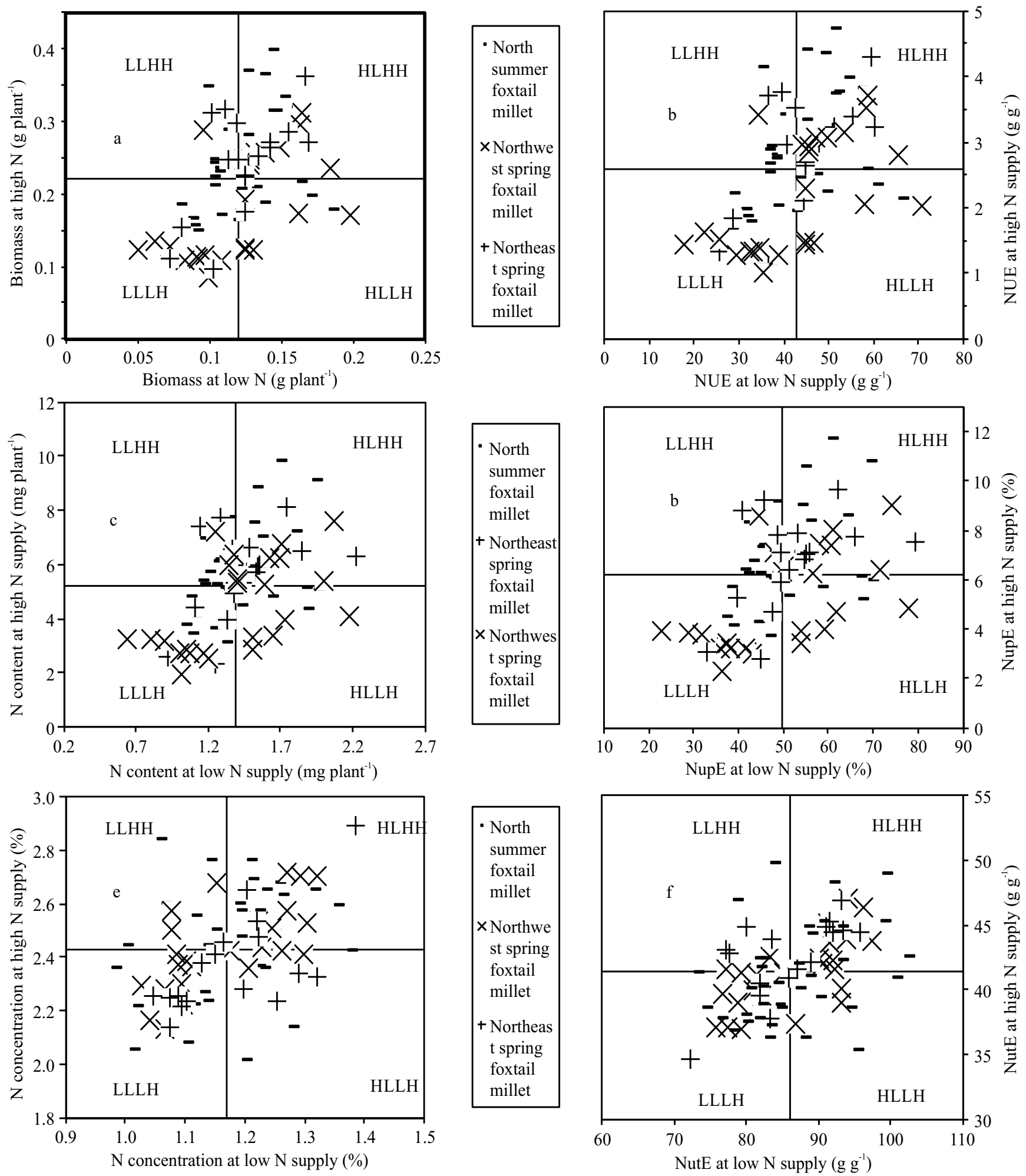

Figure 1. Classification of cultivars of three ecogeographic types, in China, according to the following means for: A, biomass; B, nitrogen use efficiency (NUE); C, N content; D, nitrogen uptake efficiency (NupE); E, N concentration; and F, nitrogen utilization efficiency (NutE) under low-nitrogen (LN) and high-nitrogen (HN) conditions. HLHH, higher than the means both under LN and HN; LLLH, lower than the means both under LN and HN; HLLH, higher than the mean under LN, and lower than the mean under HN; LLHH, lower than the mean under LN, and higher than the mean under HN. 

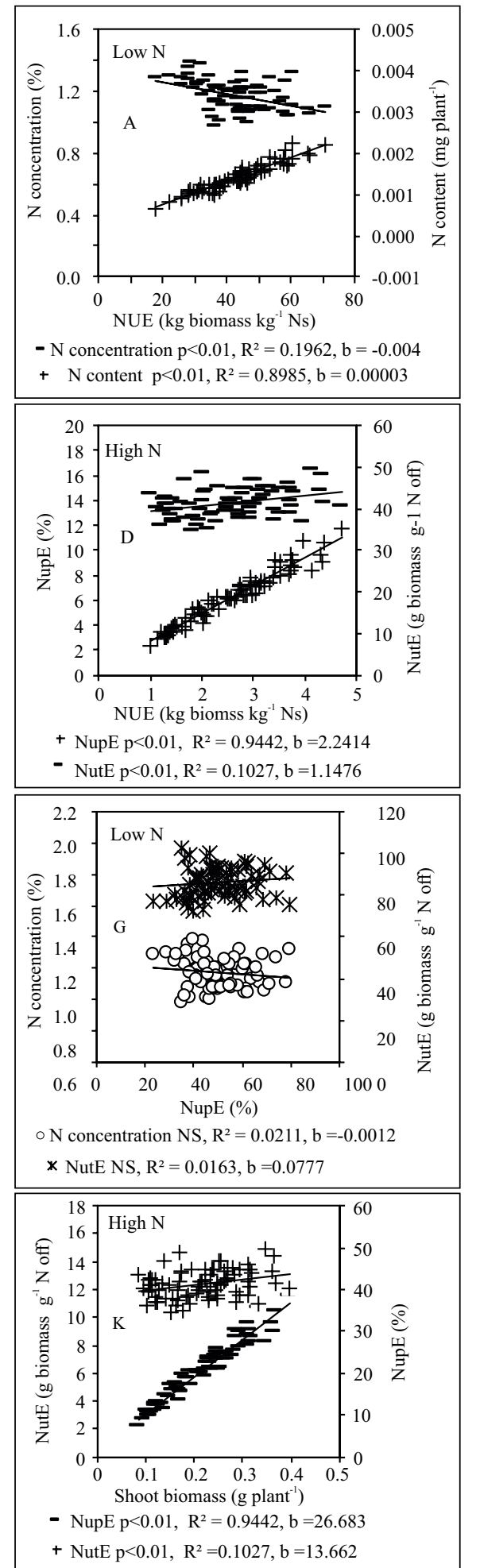

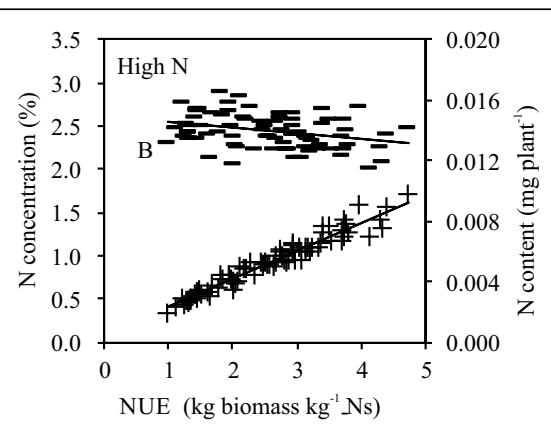

- N concentration $\mathrm{p}<0.01, \mathrm{R}^{2}=0.0998, \mathrm{~b}=-0.066$

$+\mathrm{N}$ content $\mathrm{p}<0.01, \mathrm{R}^{2}=0.9442, \mathrm{~b}=0.0019$

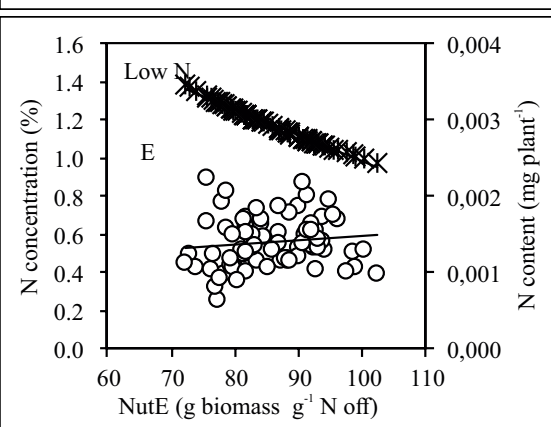

* $\mathrm{N}$ concentration $\mathrm{p}<0.01, \mathrm{R}^{2}=0.9924, \mathrm{~b}=-0.0136$

○ $\mathrm{N}$ content $\mathrm{NS}, \mathrm{R}^{2}=0.00163, \mathrm{~b}=-0.000006$

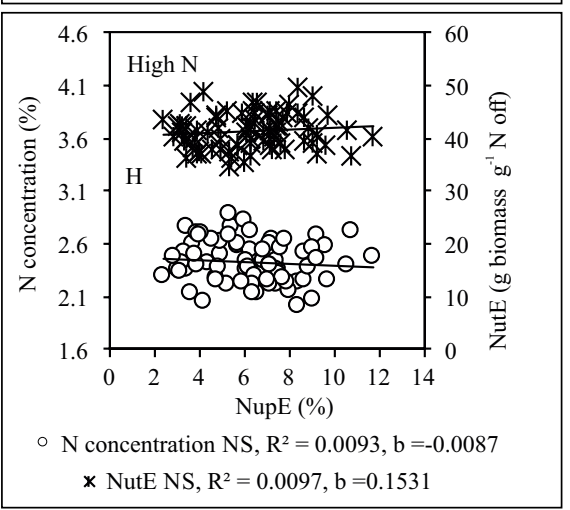

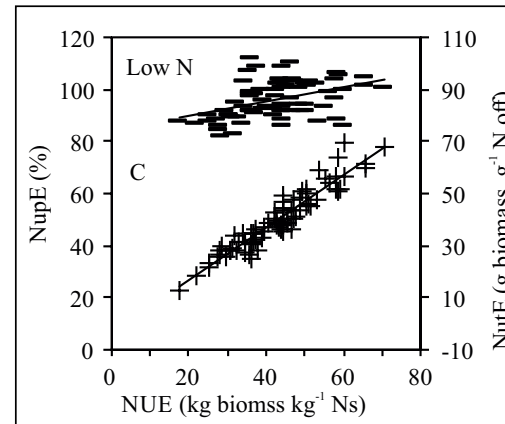

+ NupE $\mathrm{p}<0.01, \mathrm{R}^{2}=0.8985, \mathrm{~b}=1.0214$

- NutE $p<0.01, R^{2}=0.1827, b=0.2801$

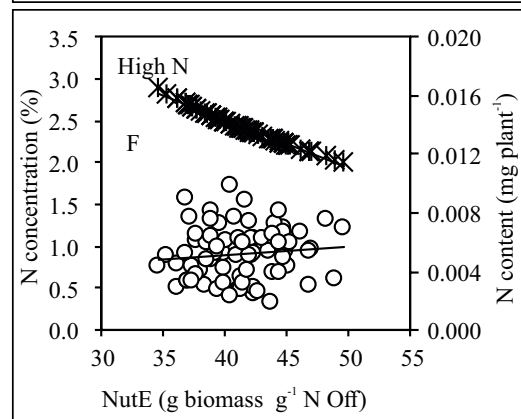

$* \mathrm{~N}$ concentration $\mathrm{p}<0.01, \mathrm{R}^{2}=0.991, \mathrm{~b}=-0.0581$ $\circ \mathrm{N}$ content $\mathrm{NS}, \mathrm{R}^{2}=0.0097, \mathrm{~b}=-0.00005$

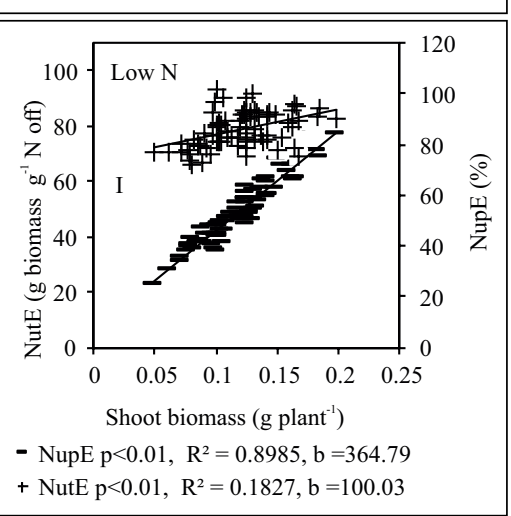

Figure 2. Relationship between the following parameters under low-nitrogen (LN) and high-nitrogen (HN) conditions: nitrogen efficiency use (NUE) with N concentration and N content under LN (A) and HN (B); NUE with its components nitrogen uptake efficiency (NupE) and nitrogen utilization efficiency (NutE) under LN (C) and $\mathrm{N}$ (D) conditions; $\mathrm{N}$ concentration with $\mathrm{N}$ content and NutE among cultivars under LN (E) and HN (F); NupE with shoot $\mathrm{N}$ concentration and NutE under LN (G) and HN (H); shoot biomass with NupE and NutE under LN (I) and HN (K). Lines fitted by linear regression $(\mathrm{y}=\mathrm{a}+\mathrm{bx})$ to mean values for individual cultivars. ${ }^{\text {NSNonsignificant. }}$ 
correlated with NupE and NutE in the present study. The correlation expresses the importance of $\mathrm{N}$ uptake and utilization for early plant growth, which was consistent with studies on wheat (Liao et al., 2004; An et al., 2006). NUE was positively correlated with $\mathrm{N}$ content, and negatively correlated with $\mathrm{N}$ concentration. By this result, it can be inferred that the cultivar with high-NUE should have high-N content and low-N concentration in the seedling stage of foxtail millet. There was no significant correlation between $\mathrm{N}$ content and NutE, and between $\mathrm{N}$ concentration and NupE, and also between NutE and NupE, which indicates that the improvement of $\mathrm{N}$ uptake and $\mathrm{N}$ utilization should be selected independently, and that the $\mathrm{N}$ content and $\mathrm{N}$ concentration should be avoided as selection criteria for NutE and NupE, respectively.

\section{Conclusions}

1. There is a large variation for shoot biomass and nitrogen use efficiency among foxtail millet cultivars, from three ecogeographic origins of China, at the seedling stage, especially for high-N levels.

2. Northwest type cultivars show the highest variation of shoot biomass, $\mathrm{N}$ content, $\mathrm{N}$ concentration, nitrogen use efficiency and nitrogen uptake efficiency than the Northeast and NC types, at seedling stage.

3. There is a large variation for nitrogen uptake and nitrogen utilization among foxtail millet cultivars; and the variation of nitrogen uptake contributes more than that of nitrogen utilization to the variation of nitrogen use efficiency.

\section{Acknowledgments}

To the Shandong Natural Science Foundation of China (ZR2017YL010), the China Agricultural Research System(CARS-06-13.5-A19), the Agricultural Scientific and Technological Innovation Project of Shandong Academy of Agricultural Sciences CXGC2018D02), and the Shandong Academy of Agricultural Sciences Foundation of China (2016YQN03).

\section{References}

AN, D.; SU, J.; LIU, Q.; ZHU, Y.; TONG, Y.; LI, J.; JING, R.; LI, B.; LI, Z. Mapping QTLs for nitrogen uptake in relation to the early growth of wheat (Triticum aestivum L.). Plant and Soil, v.284, p.73-84, 2006. DOI: https://doi.org/10.1007/s11104 -006 -0030-3.
AUSTIN, D.F. Fox-tail millets (Setaria: Poaceae)—abandoned food in two hemispheres. Economic Botany, v.60, p.143-158, 2006. DOI: https://doi.org/10.1663/ 0013-0001.

BINGHAM, I.J.; KARLEY, A.J.; WHITE, P.J.; THOMAS, W.T.B.; RUSSELL, J.R. Analysis of improvements in nitrogen use efficiency associated with 75 years of spring barley breeding. European Journal of Agronomy, v.42, p.49-58, 2012. DOI: https://doi.org/10.1016/j.eja.2011.10.003.

CHEN, X.; CUI, Z.; FAN, M.; VITOUSEK, P.; ZHAO, M.; MA, W.; WANG, Z.; ZHANG, W.; YAN, X.; YANG, J.; DENG, X.; GAO, Q.; ZHANG, Q.; GUO, S.; REN, J.; LI, S.; YE, Y.; WANG, Z.; HUANG, J.; TANG, Q.; SUN, Y.; PENG, X.; ZHANG, J.; HE, M.; ZHU, Y.; XUE, J.; WANG, G.; WU, L.; AN, N.; WU, L.; MA, L.; ZHANG, W.; ZHANG, F. Producing more grain with lower environmental costs. Nature, v.514, p.486489, 2014a. DOI: https://doi.org/10.1038/nature13609.

CHEN, Y.; XIAO, C.; CHEN, X.; LI, Q.; ZHANG, J.; CHEN, F.; YUAN, L.; MI, G. Characterization of the plant traits contributed to high grain yield and high grain nitrogen concentration in maize. Field Crops Research, v.159, p.1-9, 2014b. DOI: https://doi.org/10.1016/j.fcr.2014.01.002.

DIAO, X. Foxtail millet production and future development direction in China, in reports on minor grain development in china. In: CHAI, Y.; WAN, S.H. (Ed.). Reports on minor grain development in China. Beijing: China Agricultural Science and Technology Press, 2007. p.32-43.

DOUST, A.N.; KELlOGG, E.A.; DEVOS, K.M.; BENNETZEN, J.L. Foxtail millet: a sequence-driven grass model system. Plant Physiology, v.149, p.137-141, 2009. DOI: https://doi.org/10.1104/pp.108.129627.

GARNETT, T.; CONN, V.; KAISER, B.N. Root based approaches to improving nitrogen use efficiency in plants. Plant, Cell and Environment, v.32, p.1272-1283, 2009. DOI: https://doi.org/10.1111/j.1365-3040.2009.02011.x.

HAEGELE, J.W.; COOK, K.A.; NICHOLS, D.M.; BELOW, F.E. Changes in nitrogen use traits associated with genetic improvement for grain yield of maize hybrids released in different decades. Crop Science, v.53, p.1256-1268, 2013. DOI: https://doi.org/ 10.2135/cropsci2012.07.0429.

HOU, W.; XUE, X.; LI, X.; KHAN, M.R.; YAN, J.; REN, T.; GONG, R.; LU, J. Interactive effects of nitrogen and potassium on: grain yield, nitrogen uptake and nitrogen use efficiency of rice in low potassium fertility soil in China. Field Crops Research, v.236, p.14-23, 2019. DOI: https://doi.org/10.1016/ j.fcr.2019.03.006.

JIA, G.; HUANG, X.; ZHI, H.; ZHAO, Y.; ZHAO, Q.; LI, W.; CHAI, Y.; YANG, L.; LIU, K.; LU, H.; ZHU, C.; LU, Y.; ZHOU, C.; FAN, D.; WENG, Q.; GUO, Y.; HUANG, T.; ZHANG, L.; LU, T.; FENG, Q.; HAO, H.; LIU, H.; LU, P.; ZHANG, N.; LI, Y.; GUO, E.; WANG, S.; WANG, S.; LIU, J.; ZHANG, W.; CHEN, G.; ZHANG, B.; LI, W.; WANG, Y.; LI, H.; ZHAO, B.; LI, J.; DIAO, X.; HAN, B. A haplotype map of genomic variations and genome-wide association studies of agronomic traits in foxtail millet (Setaria italica). Nature Genetics, v.45, p.957-961, 2013. DOI: https://doi.org/10.1038/ng.2673. 
JU, C.; BURESH, R.J.; WANG, Z.; ZHANG, H.; LIU, L.; YANG, J.; ZHANG, J. Root and shoot traits for rice varieties with higher grain yield and higher nitrogen use efficiency at lower nitrogen rates application. Field Crops Research, v.175, p.47-55, 2015. DOI: https://doi.org/10.1016/j.fcr.2015.02.007.

KANT S.; BI, Y.-M.; ROTHSTEIN, S.J. Understanding plant response to nitrogen limitation for the improvement of crop nitrogen use efficiency. Journal of Experimental Botany, v.62, p.1490-1509, 2011. DOI: https://doi.org/10.1093/jxb/erq297.

LIAO, M.T.; FILLERY, I.R.P.; PALTA, J.A. Early vigorous growth is a major factor influencing nitrogen uptake in wheat. Functional Plant Biology, v.31, p.121-129, 2004. DOI: https://doi.org/10.1071/FP03060.

LIU, Z.; GAO, J.; GAO, F.; LIU, P.; ZHAO, B.; ZHANG J. Late harvest improves yield and nitrogen utilization efficiency of summer maize. Field Crops Research, v.232, p.88-94, 2019. https://doi.org/ 10.1016/j.fcr.2018.12.014.

MUURINEN, S.; SLAFER, G.A.; PELTONEN-SAINIO, P. Breeding effects on nitrogen use efficiency of spring cereals under northern conditions. Crop Science, v.46, p.561-568, 2006. DOI: https://doi.org/10.2135/cropsci2005-05-0046.

PANG J.; PALTA J.A.; REBETZKE G.J.; MILROY, S.P. Wheat genotypes with high early vigour accumulate more nitrogen and have higher photosynthetic nitrogen use efficiency during early growth. Functional Plant Biology, v.41, p.215-222, 2014. DOI: https://doi.org/10.1071/FP13143.

PENG, S.; BURESH, R.J.; HUANG, J.; ZHONG, X.; ZOU, Y.; YANG, J.; WANG, G.; LIU, Y.; HU, R.; TANG, Q.; CUI, K.; ZHANG, F.; DOBERMANN, A. Improving nitrogen fertilization in rice by site-specific N management. A review. Agronomy for Sustainable Development, v.30, p.649-656, 2010. DOI: https://doi.org/10.1051/agro/2010002.

SINGH, R.K.; CHAKRABORTY, D.; GARG, R.N.; SHARMA, P.K.; SHARMA, U.C. Effect of different water regimes and nitrogen application on growth, yield, water use and nitrogen uptake by pearl millet (Pennisetum glaucum). Indian Journal of Agricultural Science, v.80, p.213-216, 2010.

STORER, K.E.;BERRY, P.M.; KINDRED, D.R.; SYLVESTERBRADLEY, R. Identifying oilseed rape varieties with high yield and low nitrogen fertiliser requirement. Field Crops Research, v.225, p.104-116, 2018. DOI: https://doi.org/10.1016/j. fcr.2018.06.005.

SYLVESTER-BRADLEY, R.; KINDRED, D.R. Analysing nitrogen responses of cereals to prioritize routes to the improvement of nitrogen use efficiency. Journal of Experimental Botany, v.60, p.1939-1951, 2009. DOI: https://doi.org/10.1093/jxb/erp116.

UPADHYAYA, H.D.; RAVISHANKAR, C.R.; NARASIMHUDU, Y.; SARMA, N.D.R.K.; SINGH, S.K.; VARSHNEY, S.K.; REDDY, V.G.; SINGH, S.; PARZIES, H.K.; DWIVEDI, S.L.; NADAF, H.L.; SAHRAWAT, K.L.; GOWDA, C.L.L. Identification of trait-specific germplasm and developing a mini core collection for efficient use of foxtail millet genetic resources in crop improvement. Field Crops Research, v.124, p.459-467, 2011. DOI: https://doi.org/10.1016/j.fcr.2011.08.004.

VETRIVENTHAN, M.; UPADHYAYA, H.D.; ANANDAKUMAR, C.R.; SENTHILVEL, S.; PARZIES, H.K.; BHARATHI,A.;VARSHNEY,R.K.;GOWDA,C.L.L.Assessing genetic diversity, allelic richness and genetic relationship among races in ICRISAT foxtail millet core collection. Plant Genetic Resources, v.10, p.214-223, 2012. DOI: https://doi.org/10.1017/ S1479262112000287. 